\title{
26. LATE CRETACEOUS-CENOZOIC MAGNETOSTRATIGRAPHIC AND BIOSTRATIGRAPHIC CORRELATIONS FOR THE SOUTH ATLANTIC OCEAN, DEEP SEA DRILLING PROJECT LEG 731
}

\author{
Richard Z. Poore, ${ }^{2}$ Lisa Tauxe, ${ }^{3}$ Stephen F. Percival, Jr., ${ }^{4}$ John L. LaBrecque, ${ }^{3}$ Ramil Wright, ${ }^{5}$ \\ Nikolai P. Petersen, ${ }^{6}$ Charles C. Smith, ${ }^{7}$ Peter Tucker, ${ }^{8}$ and Kenneth J. Hsü ${ }^{9}$
}

\begin{abstract}
DSDP Leg 73 sediment cores allow direct calibrations of magnetostratigraphy and biostratigraphy for much of the latest Cretaceous to Cenozoic in the midlatitude South Atlantic Ocean. The record of the Cenozoic was incomplete, because strong dissolution, poor core recovery, and intense core disturbance masked the biostratigraphy or magnetostratigraphy in some intervals of the recovered sections. DSDP Leg 73 results show the following correlations: early/middle Miocene-in Chron 16; Oligocene/Miocene-within Subchron C-6C-N; Eocene/Oligocene-within Subchron C-13-R; middle/late Eocene-top of Chron C-17; early/late Paleocene-top of Subchron C-27-N; Cretaceous/Tertiary-within Subchron C-29-R.
\end{abstract}

\section{INTRODUCTION}

Many of the sediment cores recovered during DSDP Leg 73 yielded reliable magnetic polarity signatures and stratigraphically diagnostic calcareous microfossils. Therefore Leg 73 cores provide the opportunity for a direct calibration of magnetostratigraphy and biostratigraphy for much of the latest Cretaceous to Cenozoic in the midlatitude South Atlantic.

In the following sections we plot and interpret the stratigraphic distribution of selected microfossils and the magnetic polarity history for five of the six sites occupied during DSDP Leg 73 (Fig. 1, Table 1). The cores recovered at Site 520 were not suitable for magnetostratigraphy and are not considered in this report. Over some stratigraphic intervals our calibrations duplicate calibrations made in previous studies. They thus provide a test of existing models and allow evaluation of the chronostratigraphic reliability of key microfossil events. Over other stratigraphic intervals our data represent new direct correlations of magnetostratigraphy and biostratigraphy and thus provide new standards. We avoid numerical magnetostratigraphic ages in most of the following sections, because assigning ages to magnetic reversals or biostratigraphic events older than late Miocene involves assumptions and interpretations that are beyond the scope of this contribution. We do, however, discuss ages during the interpretation of the late Miocene and early Pliocene sequence of Site 519, because the late Neogene polarity record is fairly well understood.

\footnotetext{
${ }^{1}$ Hsü, K. H., LaBrecque, J. L., et al., Init. Repts. DSDP, 73: Washington (U.S. Govt. Printing Office).

2 U.S. Geological Survey, Reston, Virginia.

3 Lamont-Doherty Geological Observatory, Columbia University, Palisades, New York (present address for L. Tauxe: Scripps Institution of Oceanography, La Jolla, California).

4 Mobil Exploration and Producing Services, Inc., Dallas, Texas.

5 Exxon Production Research Company, Houston, Texas.

6 Institut für Allgemeine und Angewandte Geophysik, Universität München, There-

sienstr. 41, D-8000 Munich, Federal Republic of Germany.

7 U.S. Geological Survey, Washington, D.C.

8 University of Edinburgh, Mayfield Road, Edinburgh, United Kingdom.

9 Eidgenössische Technische Hochschule Zürich, CH-8092 Zürich, Switzerland.
}

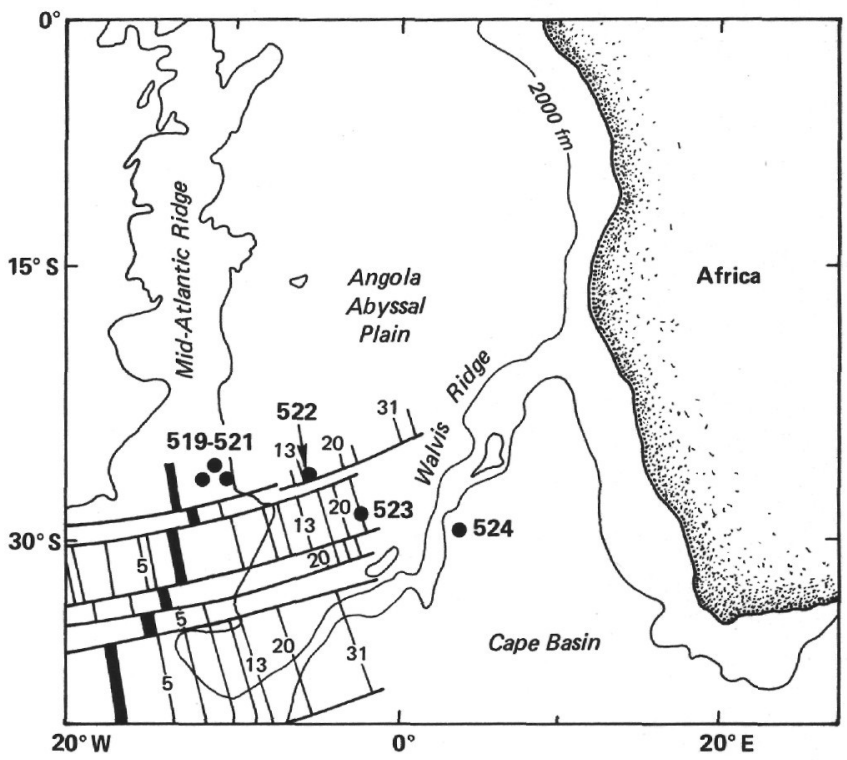

Figure 1. Sketch map showing location of Leg 73 sites.

\section{MATERIALS AND METHODS}

\section{Magnetostratigraphy}

Polarity measurements were made on board ship on oriented 7-cc samples taken at intervals of 10 to $40 \mathrm{~cm}$. All samples were subjected to alternating field demagnetization. Polarities deduced from the inclinations are depicted in the figures by using black to represent intervals of normal polarity and white to represent intervals of reversed polarity. The results of individual magnetic measurements are given in the site chapters, and the magnetic data are discussed in detail by Tauxe et al. (this vol.). The chron terminology used for the magnetic units follows Tauxe et al. (this vol.). Briefly, Paleogene chrons are defined as the interval between the youngest reversal boundaries of numbered magnetic anomalies; the numbered magnetic anomalies are those of Heirtzler et al. 
Table 1. Latitude, longitude, and water depth (corrected m) of DSDP Leg 73 sites.

\begin{tabular}{lllc}
\hline Site & Latitude & Longitude & $\begin{array}{c}\text { Water } \\
\text { depth (m) }\end{array}$ \\
\hline 519 & $26^{\circ} \mathrm{S}$ & $1^{\circ} 40^{\prime} \mathrm{W}$ & 3769 \\
520 & $25^{\circ} 31^{\prime} \mathrm{S}$ & $11^{\circ} 11^{\prime} \mathrm{W}$ & 4207 \\
521 & $26^{\circ} 43^{\prime} \mathrm{S}$ & $10^{\circ} 16^{\prime} \mathrm{W}$ & 4125 \\
522 & $26^{\circ} 07^{\prime} \mathrm{S}$ & $5^{\circ} 08^{\prime} \mathrm{W}$ & 4441 \\
523 & $28^{\circ} 33^{\prime} \mathrm{S}$ & $2^{\circ} 15^{\prime} \mathrm{W}$ & 4573 \\
524 & $29^{\circ} 29^{\prime} \mathrm{S}$ & $3^{\circ} 31^{\prime} \mathrm{E}$ & 4796 \\
\hline
\end{tabular}

(1968) as refined by LaBrecque et al. (1977). These chrons are distinguished from the previously defined Neogene chrons by the prefix C. For example, Chron C-12 is the interval from the top of Anomaly 12 to the top of Anomaly 13. Chrons may be divided into subchrons of predominantly normal or predominantly reversed magnetization and are designated by adding an $\mathrm{N}$ or $\mathrm{R}$ suffix to the chron. Thus, the reversed interval of Chron 12 is Subchron C-12-R.

\section{Biostratigraphy}

The stratigraphic distribution of microfossils shown in Figures 2 through 7 is modified from the occurrence charts of Percival (this vol., calcareous nannofossils), Poore (this vol., planktonic foraminifers) and Smith and Poore (this vol., planktonic foraminifers). In general, one sample per section was studied for calcareous nannofossils, whereas one sample every other section was studied for foraminifers. It was noted during the study of the Leg 73 material that many hydraulic piston corer (HPC) core-catcher samples showed clear evidence of downhole contamination. Therefore, lowest occurrences (i.e., oldest stratigraphic occurrences) of fossils in HPC core-catcher samples are not be considered reliable, and those samples were not used to establish the lower stratigraphic limits shown in the figures. Thus, by this convention (the Leg 73 HPC core-catcher convention), the lower limits of the fossil ranges shown in the figures represent the lowest within-core occurrences of the various taxa. Reworking of older fossils into younger horizons was also noted in some samples. Occurrences of taxa that are obviously due to reworking were not used to construct the ranges or interpretations shown in Figures 2 and 4 to 7.

Cenozoic calcareous nannofossil distributions are used to identify the standard NN and NP zones of Martini (1971). For some sections the widely used zones of Bukry $(1973 ; 1975)$ as codified into $\mathrm{CN}$ and CP zones by Okada and Bukry (1980) are also identified.

No single standard foraminifer zonation was found suitable for the foraminifer assemblages recovered during Leg 73. The zonation of Stainforth et al. (1975), supplemented by the middle Eocene zonation of Toumarkine and Bolli (1970), and an Oligocene zonation defined by Poore (this vol.) were used for the Paleogene of Sites 522 through 524. The zonation of Berggren (1973; 1977) was useful for the Pliocene assemblages from
Hole 519, and the standard zonation of Blow (1969) was generally useful in the Miocene of Holes 519 and 521.

In the following diagrams, zone boundaries delineated by solid lines are recognized by primary criteria; boundaries delineated by dashed lines are estimated from secondary indicators. Qualitative abundance estimates were made from smear slides for calcareous nannofossils and strewn slides for foraminifers.

\section{SITE 519}

The magneto- and biostratigraphies for Cores 15 through 36 of Hole 519 are shown in Figure 2. The upper part of the sedimentary section recovered at Hole 519 contains a number of slumps that have mixed together fossil assemblages of various ages. For example, the abrupt disappearance of several Discoaster spp. and Pseudoemiliana lacunosa and the reappearance of $\mathbf{R e}$ ticulofenestra pseudoumbilica and several Amaurolithus spp. in Core 15 mark the base of a major slump. Therefore, no attempt was made to calibrate the magneto- and biostratigraphies in the upper part of the section. The calcareous microfossils are moderately well preserved in Cores 15 through 24 but show effects of dissolution in Cores 25 through 36. Dissolution is most pronounced in Cores 28 through 30; the foraminifer assemblages appear to be more affected by dissolution than the calcareous nannofossil assemblages.

The interpretation of the magnetostratigraphy is clear except in Cores 29 and 30. Site 519 was located between Anomaly 5 and Anomaly 5A. Thus, the thick normal event seen at the base of the sedimentary section is Chron 9, and the base of Chron 7 occurs in the top of Core 32 . The polarity pattern and associated microfossils in Cores 16 through 27 show that the Gauss/Gilbert boundary is in Core 18, that the Gilbert chron extends down through Core 27, and that the normal event in Core 28 is the top of Chron 5. The interpretation shown in Figure 2 for Cores 29 and 30 suggests the presence of an unconformity in the lower part of Core 29 that brings Chron 7 in contact with Chron 5. Microfossil distributions support this interpretation; there is a marked floral and faunal break in the lower part of Core 29. Several calcareous nannofossils first occur in Sections 2 and 1 , and two planktonic foraminifers, including Globigerinoides kennetti, last occur in Section 3. The last occurrence of G. kennetti in Section 3 is significant, because indirect calibrations done in the Pacific basin indicate that the last occurrence of $G$. kennetti is early in Chron 7 (Keller et al., in press). Thus, Core $\mathbf{3 0}$ and the bottom of Core 29 are probably still early Chron 7 . The preferred interpretation is that an unconformity representing part of Chron 7, all of Chron 6, and possibly part of Chron 5 is present in Core 29. An alternative interpretation, which is considered unlikely by the senior author, is that a continuous, albeit highly condensed, section is present in Core 29 and that the reversed interval at the base of Core 29 is Chron 6.

Primary calcareous nannofossil zone indicators are absent from the lower part of Hole 519, and the highest occurrence of Catinaster calyculus is used to approxi- 


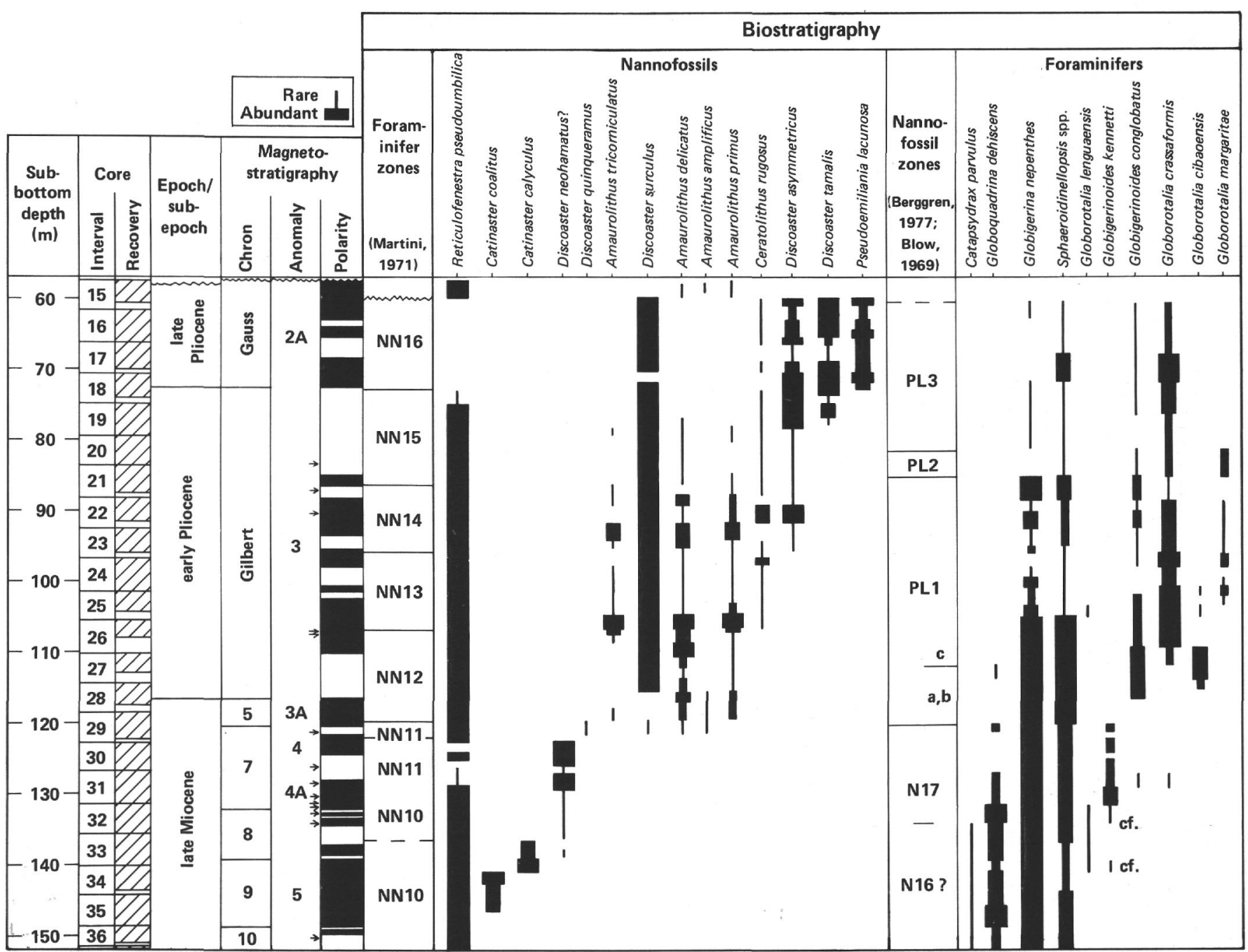

Figure 2. Summary of magnetostratigraphy and biostratigraphy for Hole 519. Arrows next to polarity column show events too brief to plot; cf. $=$ tentative identification. Zone boundaries are plotted between control points.

mate the upper limit of Zone NN10. Assemblages in Cores 30 through 33 could represent NN10 or NN11. The remaining zone boundaries are delineated by primary indicators.

The standard foraminifer zones of Blow (1969) can only be approximated in Hole 519. Assemblages below Core 29 are highly dissolved and are only indicative of a general late Miocene, Zone N16-N17 assignment. The Pliocene zonation of Berggren $(1973 ; 1977)$, however, is easy to recognize at Hole 519.

The ages of several selected magnetostratigraphic boundaries were used to construct a chronology for Hole 519 (Fig. 3). Age estimates are from LaBrecque et al. (1977) as corrected for new decay constants by Mankinen and Dalrymple (1979). The age-depth plot for Hole 519 was then used to estimate the ages of selected calcareous nannofossil and planktonic foraminifer events (highest occurrences, HO, and lowest occurrences, LO). The paleomagnetic events used to construct Figure 3 are listed in Table 2. The estimated ages of the microfossil events shown in Figure 3 are listed in Table 3. The effects of downhole contamination and reworking have been taken into consideration in constructing both Table
3 and Figure 3. For example, Globigerina nepenthes in Cores 18 and 19 are considered reworked, and Globigerinoides conglobatus and Globorotalia crassaformis in Core $\mathbf{3 1}$ are considered downhole contamination.

The age estimates shown in Table 3 for the LOs of G. cibaoensis, Globigerinoides conglobatus, G. kennet$t i$, Catinaster coalitus, and C. calyculus and the HOs of Globorotalia lenguaensis, Catapsydrax parvulus, Catinaster calyculus, and $C$. coalitus represent the first directly controlled estimates for these events. How closely these Hole 519 events approach the absolute HOs or LOs of the various taxa cannot be evaluated until calibrations are made in other sections. Note that indirect calibrations made in the equatorial Pacific suggest that the absolute LO or FAD (first appearance datum) of C. coalitus is near the Chron 12 /Chron 11 boundary and that the FAD of Globigerinoides conglobatus is in Chron 7.

The Hole 519 age estimates for the LOs of $P$. lacunosa and Discoaster tamalis and the HOs of Amaurolithus tricorniculatus and Globigerina nepenthes are nearly identical to age estimates derived for these events in paleomagnetically dated piston cores from the equatorial 


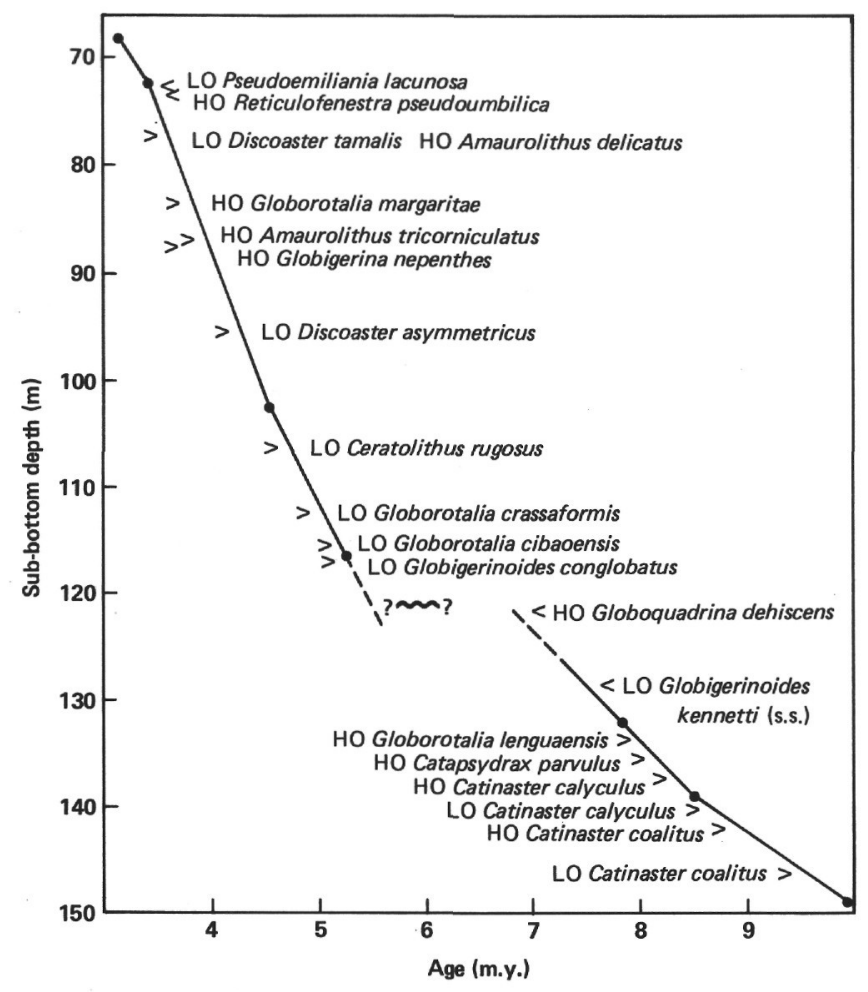

Figure 3. Chronology model for Hole 519. Selected paleomagnetic events were used to construct the time-depth plot. Location and assigned age for paleomagnetic control points (solid dots) are listed in Table 2. Estimated ages for selected biostratigraphic events determined from the time-depth plot are listed in Table 3. HO = highest occurrence; $\mathrm{LO}=$ lowest occurrence.

Table 2. Location of paleomagnetic control points (Hole 519) used to construct the time versus depth plot for Figure 3.

\begin{tabular}{lccc}
\hline \multicolumn{1}{c}{ Control point } & $\begin{array}{c}\text { Age } \\
\text { (m.y.) }\end{array}$ & $\begin{array}{c}\text { Core- } \\
\text { Section } \\
\text { (level in cm) }\end{array}$ & $\begin{array}{c}\text { Sub-bottom } \\
\text { depth (m) }\end{array}$ \\
\hline Base of Mammoth & 3.18 & $17-2,90$ & 68.5 \\
Gilbert/Gauss & 3.41 & $18-2,50$ & 72.5 \\
Top of C-2 & 4.25 & $25-1,120$ & 102.5 \\
Chron 5/Gilbert & 5.26 & $28-2,5$ & 116.5 \\
Chron 8/Chron 7 & 7.88 & $32-1,90$ & 132.2 \\
Chron 9/Chron 8 & 8.56 & $33-3,55$ & 139.2 \\
Chron 10/Chron 9 & 10.0 & $36-1,60$ & 149.1 \\
\hline
\end{tabular}

Pacific (Hays et al., 1969; Gartner, 1973; Saito et al., 1975). Thus, these biostratigraphic events are synchronous in the equatorial Pacific and the midlatitude South Atlantic. Further, the age estimates for these events probably represent their FADs and LADs (last appearance datums). The HO of $R$. pseudoumbilica appears to be older in Hole 519 than it is in the equatorial Pacific, but this difference is probably due to the difficulty of separating $R$. pseudoumbilica (s.s.) and (s.l.) (Haq and Berggren, 1978). The HO observed and calibrated in Hole 519 refers to $R$. pseudoumbilica (s.s.).

The LOs of $D$. asymmetricus, Ceratolithus rugosus, and Globorotalia crassaformis are older than previous direct and indirect calibrations have suggested. Thus,
Table 3. Estimated ages for selected biostratigraphic events in Hole 519.

\begin{tabular}{llcc}
\hline \multicolumn{1}{c}{ Event } & \multicolumn{1}{c}{ Core-Section } & $\begin{array}{c}\text { Sub-bottom } \\
\text { depth } \\
\text { (m) }\end{array}$ & $\begin{array}{c}\text { Age } \\
\text { (m.y.) }\end{array}$ \\
\hline LO Pseudoemiliania lacunosa & $18-2,90-91$ & 72.9 & 3.42 \\
HO Reticulofenestra pseudoumbilica & $18-3,6-7$ & 73.56 & 3.45 \\
LO Discoaster tamalis & $19-2,120-122$ & 77.6 & 3.60 \\
HO Amaurolithus delicatus & $19-2,120-122$ & 77.6 & 3.60 \\
HO Globorotalia margaritae & 20, CC & 83.5 & 3.81 \\
HO Amaurolithus tricorniculatus & $21-3,20-21$ & 86.9 & 3.93 \\
HO Globigerina nepenthes & 21, CC & 87.5 & 3.98 \\
LO Discoaster asymmetricus & $23-3,35-36$ & 95.9 & 4.28 \\
LO Ceratolithus rugosus & $26-1,72-73$ & 106.4 & 4.72 \\
LO Globorotalia crassaformis & $27-2,100-102$ & 112.4 & 5.05 \\
LO Globorotalia cibaoensis & $28-1,103-105$ & 115.55 & 5.20 \\
LO Globigerinoides conglobatus & $28-2,103-105$ & 117 & 5.30 \\
HO Globoquadrina dehiscens & $29-3,30-32$ & 121.8 & 6.90 \\
LO Globigerinoides kennetti (s.s.) & $31-2,42-44$ & 128.8 & 7.50 \\
HO Globorotalia lenguaensis & $32-2,124-126$ & 134 & 8.10 \\
HO Catapsydrax parvulus & 32, CC & 135.7 & 8.20 \\
HO Catinaster calyculus & $33-2,45-46$ & 137.7 & 8.35 \\
LO Catinaster calyculus & $34-1,70-71$ & 140.8 & 8.75 \\
HO Catinaster coalitus & $34-2,70-71$ & 142.3 & 9.0 \\
LO Catinaster coalitus & $35-2,79-80$ & 146.4 & 9.6 \\
\hline
\end{tabular}

${ }^{a}$ HO $=$ highest occurrence, $\mathrm{LO}=$ lowest occurrence. Occurrences judged to be the result of reworking or downhole contamination were ignored.

b Or 5.5 m.y., depending on chronology of Cores 29 and 30 (see text).

the Hole 519 calibrations establish new FADs for these taxa. Note, however, that recognizing the first evolutionary occurrence of $G$. crassaformis can be difficult (Berggren, 1977).

The HOs of Globoquadrina dehiscens and Globorotalia margaritae in Hole 519 are older than their LADs in the equatorial Pacific (e.g., Saito et al., 1975). The age of the HO of Globoquadrina dehiscens depends upon one's interpretation of the chronology of Cores 29 and 30 but is either significantly older $(6.9 \mathrm{~m} . \mathrm{y}$. old $)$ or slightly older (5.5 m.y. old) than the 5.2-m.y. age derived from the Pacific. Similarly, the HO of Globorotalia marguritae in Hole 519 is 0.5 m.y. older than its established LAD of 3.3 m.y. Note, however, that the HOs of Globoquadrina dehiscens and Globorotalia margaritae fall correctly in the sequence of Pliocene foraminifer biostratigraphic events used in the widely accepted zonation of Berggren (1973). That is, the HOs of Globoquadrina dehiscens, Globigerina nepenthes, Globorotalia margaritae, and Sphaeroidinellopsis spp. appear in ascending order. Thus, without magnetostratigraphy for control, one would probably assume that the highest occurrences of Globoquadrina dehiscens, Globigerina nepenthes, and Globorotalia margaritae were synchronous in Hole 519 and the equatorial Pacific.

\section{SITE 521}

The magneto- and biostratigraphies for the lower part of Hole 521 are shown in Figure 4. Although the microfossil assemblages, especially the foraminifers, show effects of dissolution, data from Hole 521 are important for constraining the positions of the early/middle Miocene boundary and the Orbulina datum with respect to magnetostratigraphy.

Site 521 was drilled on Anomaly 5C. Thus, the normal interval starting in the bottom of Core 20 is identified as Chron 16, and the split normal event in the lower 


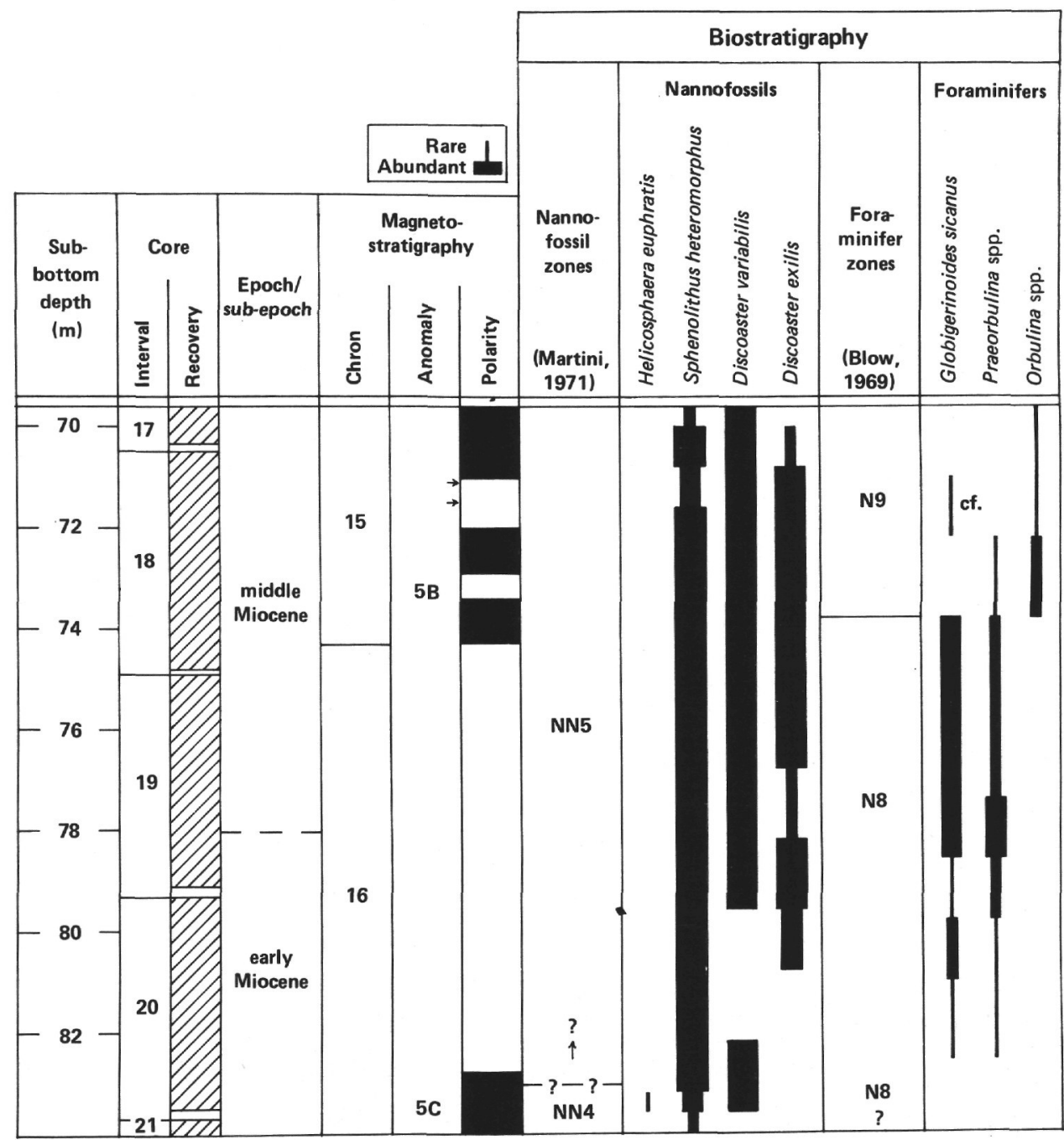

Figure 4. Summary of magnetostratigraphy and biostratigraphy for Hole 521. Arrows next to polarity column show events too brief to plot; cf. = tentative identification.

part of Core 18 represents the bottom of Chron 15 . Interpretation of the Miocene to lower Pliocene polarity sequence above Core 18 is equivocal (see Tauxe et al., this vol.).

The last occurrence of Helicosphaera euphratis is used as the approximate NN4/NN5 boundary in Hole 521 . Alternatively, the first occurrence of Discoaster exilis could be used to approximate the boundary. In either case, the secondary indicators probably represent a low (old) estimate for the true boundary. Globigerinoides sicanus occurs in Samples 521-20,CC and 521-21,CC, but because of the Leg 73 HPC core-catcher convention the lower limit of $G$. sicanus is plotted at its lowest withincore occurrence. Thus, the base of the section can only tentatively be assigned to Zone N8.

Biostratigraphic study of type sections shows that the base of the middle Miocene (the base of the Langhian Stage) falls in Zone N8 and is just below the base of calcareous nannofossil Zone NN5 (see summary in Ryan et al., 1975). Hole 521 data show that the early/middle Miocene boundary must be older than Chron 15 and that it probably falls within the upper (reversed) part of Chron 16.
The results from Hole 521 are compatible with the indirect calibrations suggested by Ryan et al. (1975) and LaBrecque et al. (1977). The Hole 521 results, however, show that the indirect calibrations constructed by Ness et al. (1980) and Lowrie and Alvarez (1981), which place the early/middle Miocene boundary up in Chron 15, require revision.

\section{SITE 522}

The magneto- and biostratigraphies for Cores 14 through 38 of Hole 522 and Cores 29 through 31 of Hole 522A are summarized in Figure 5. This section appears to be continuous from the latest Eocene to the earliest Miocene. The Miocene to Pliocene section above Core 14 is highly dissolved and is not considered further.

Site 522 was located over Anomaly 16. Thus, the normal event observed in Hole 522A, Core 31A is identified as the top of Chron C-16. Comparison of the polarity pattern of Hole 522 with the standard magnetic anomaly pattern (e.g., LaBrecque et al., 1977) indicates that the reversed interval extending from lower Core 28 into Core 33 represents the characteristically long reversed interval of Subchron C-12-R. With these assignments as 


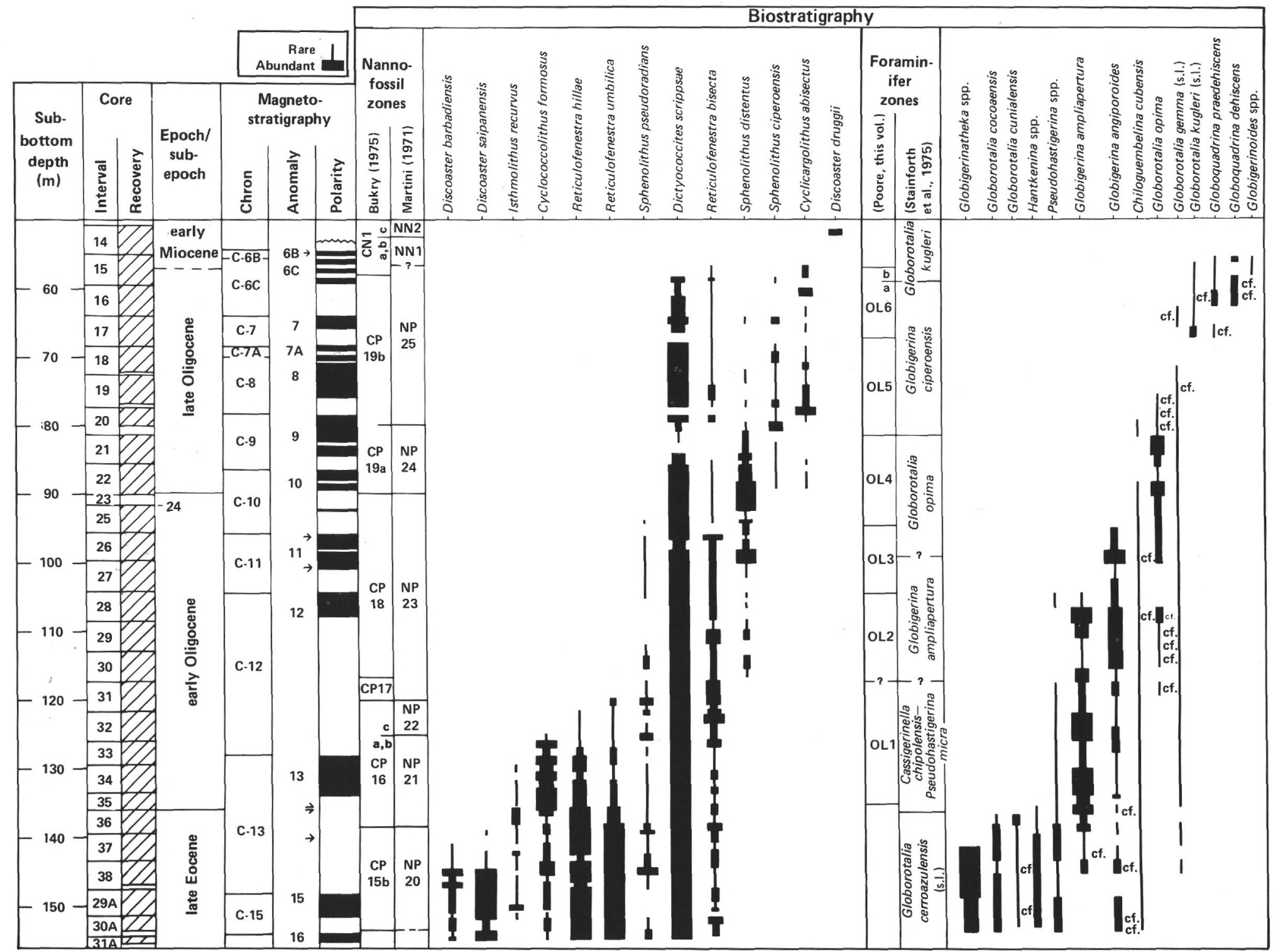

Figure 5. Summary of magnetostratigraphy and biostratigraphy for Holes 522 and the lower part of Hole 522A. Cores from Hole 522A are identified by an A suffix. Arrows next to polarity column show events too brief to plot; cf. = tentative identification. Zone boundaries are plotted between control points. 
a starting point it becomes possible to identify Chrons $\mathrm{C}-15$ and $\mathrm{C}-11$ through $\mathrm{C}-6 \mathrm{~B}$, and the resulting polarity record (Fig. 5) closely matches the standard magnetic anomaly pattern.

Calcareous nannofossils are abundant up through Core 14, but preservation declines upsection. Discoasters and sphenoliths often exhibit secondary calcite overgrowths. Most primary zonal markers are present, however, and Zones NP20 through NN2 can readily be recognized. Only the position of the NP25/NN1 boundary had to be estimated by using secondary indicators. Similarly, Zones CP15b through CN1c are easy to identify. The only problems are that Subzones $a$ and $b$ of Zones CP16 and CN1 cannot be separated.

Primary boundary indicators for the zonation of Stainforth et al. (1975) occur in the foraminifer assemblages from Holes 522 and 522A, but the exact limits of the Globigerina ampliapertura Zone are uncertain because of taxonomic problems in identifying the lowest occurrence of "typical" Globorotalia opima and the isolated occurrence of Pseudohastigerina in Core 28. The preferred interpretation is that the lowest (oldest) occurrence of "typical" G. opima is in Core 26 and that the isolated occurrence of Pseudohastigerina in Core 28 is due to reworking. The boundaries of the Globigerina ampliapertura Zone shown in Figure 5 are dashed, however, because other interpretations are possible. Recognition of the remaining zones of Stainforth et al. (1975) is based on the distribution of primary indicators. The second foraminifer zonation for the Oligocene shown in Figure 5 is proposed by Poore (this vol.). Oligocene Zones OL1 to OL6 are delineated respectively by the last occurrences of Globorotalia cerroazulensis (s.1.)/Hantkenina spp., Pseudohastigerina spp., Globigerina ampliapertura, G. angiporoides, Globorotalia opima, and the first occurrences of G. kugleri (s.l.) and Globoquadrina dehiscens (s.s.). Note that if the occurrence of Pseudohastigerina in Core 28 is considered in situ, Zone OL2 is eliminated.

Commonly used biostratigraphic criteria for recognizing the Eocene/Oligocene boundary include the last occurrences of Globorotalia cerroazulensis (s.1.), Hantkenina spp., Discoaster barbadiensis, and $D$. saipanensis. These events all occur at 138 to $140 \mathrm{~m}$ sub-bottom in Hole 522 and indicate that the Eocene/Oligocene boundary is within Core 36. In detail, Hole 522 data confirm that the top of the $G$. cerroazulensis Zone is within NP21. The early/late Oligocene boundary (the base of the Chattian Stage) is now considered to be approximated by the first occurrence of Sphenolithus ciperoensis (C. Ritzkowski, pers. comm., 1982).

Several of the biostratigraphic events in Hole 522 have been proposed as markers of the Oligocene/Miocene boundary. For planktonic foraminifers the boundary is supposed to occur (for example) above or at the first occurrence of G. kugleri (s.s.), near or above the first occurrence of Globigerinoides, or near or just below the first occurrence of Globoquadrina dehiscens. In the calcareous nannofossils record, the Oligocene/Miocene boundary is considered to be near or at the last occurrence of S. ciperoensis, Reticulofenestra bisecta,
Dictyococcites scrippsae, and Cyclicargolithus abisectus and below the first occurrence of Discoaster druggii. The distribution of microfossils in Figure 5 indicates that the Oligocene/Miocene boundary occurs within Core 15 at 56 to $58 \mathrm{~m}$ sub-bottom.

Hole 522 calibrations show that the Eocene/Oligocene boundary occurs in Subchron C-13-R. Thus the Hole 522 data corroborate the calibrations from the Gubbio area of Italy (Lowrie and Alvarez, 1981; Lowrie et al., 1982) and conflict with the correlation of the Eocene/ Oligocene boundary with Chron C-16 (Ness et al., 1980). The Oligocene/Miocene boundary appears to fall within Subchron C-6C-N, but our data do not preclude placement of the boundary within Chron C-6B. The results from Hole 522 show that previous indirect calibrations of this boundary (e.g., Lowrie and Alvarez, 1981) need slight revision.

\section{SITE 523}

Figure 6 summarizes the magneto- and biostratigraphies for Cores 21 through 50 of Hole 523. Reliable and interpretable polarity measurements could not be made above Core 21 because of poor core recovery and core disturbance.

Site 523 was located on Anomaly 21, but technical difficulties forced termination of the hole at a level estimated to be 5 to $20 \mathrm{~m}$ above basement. Thus, the normal interval in Cores 41 through 44 is identified as Subchron C-20-N. Identifications of Chrons C-19 through C-17 and the base of Chron C-16 follow from comparison with the standard magnetic anomaly pattern. Nannofossil biostratigraphy, combined with the characteristic pattern of two normal intervals separated by a very long reversed interval, leads to recognition of Chrons $\mathrm{C}-13$ and $\mathrm{C}-12$ above Core 28. Thus, the top of Chron C-16 and Chron C-15 apparently occur in the unrecovered interval of Core 29.

Calcareous nannofossils are abundant and moderately well preserved throughout Cores 21 through 50 . Recognition of Zones CP13b through CP18 is straightforward and based on primary indicators. The only problem is that Subzones a and b of CP16 cannot be separated. Recognition of Zones NP15 through NP23 is less certain, and secondary indicators must be used to approximate a number of zone boundaries. Specifically, the total range of Chiasmolithus gigas is used to correlate to NP15, and the last occurrence of Nannotetrina fulgens is used to approximate the lower limit of unequivocal NP16 floras. The flora in Cores 43 through 45 could correlate with NP15 or NP16. The last $C$. grandis is used to approximate the top of NP17 instead of the isolated occurrences of $C$. oamaruensis. Delineating the top of NP17 by the first $C$. oamaruensis would raise the boundary a meter or so in the section but would not significantly change the calibration to magnetostratigraphy. Because of the Leg 73 core-catcher convention, the lowest occurrence of Sphenolithus pseudoradians is below the lowest occurrence of Isthmolithus recurvus. Thus, NP19 is not present and the NP18/NP10 boundary is in the lower part of Core 28. An alternative interpretation would be that the lowest occurrence of $I$. recurvus and 


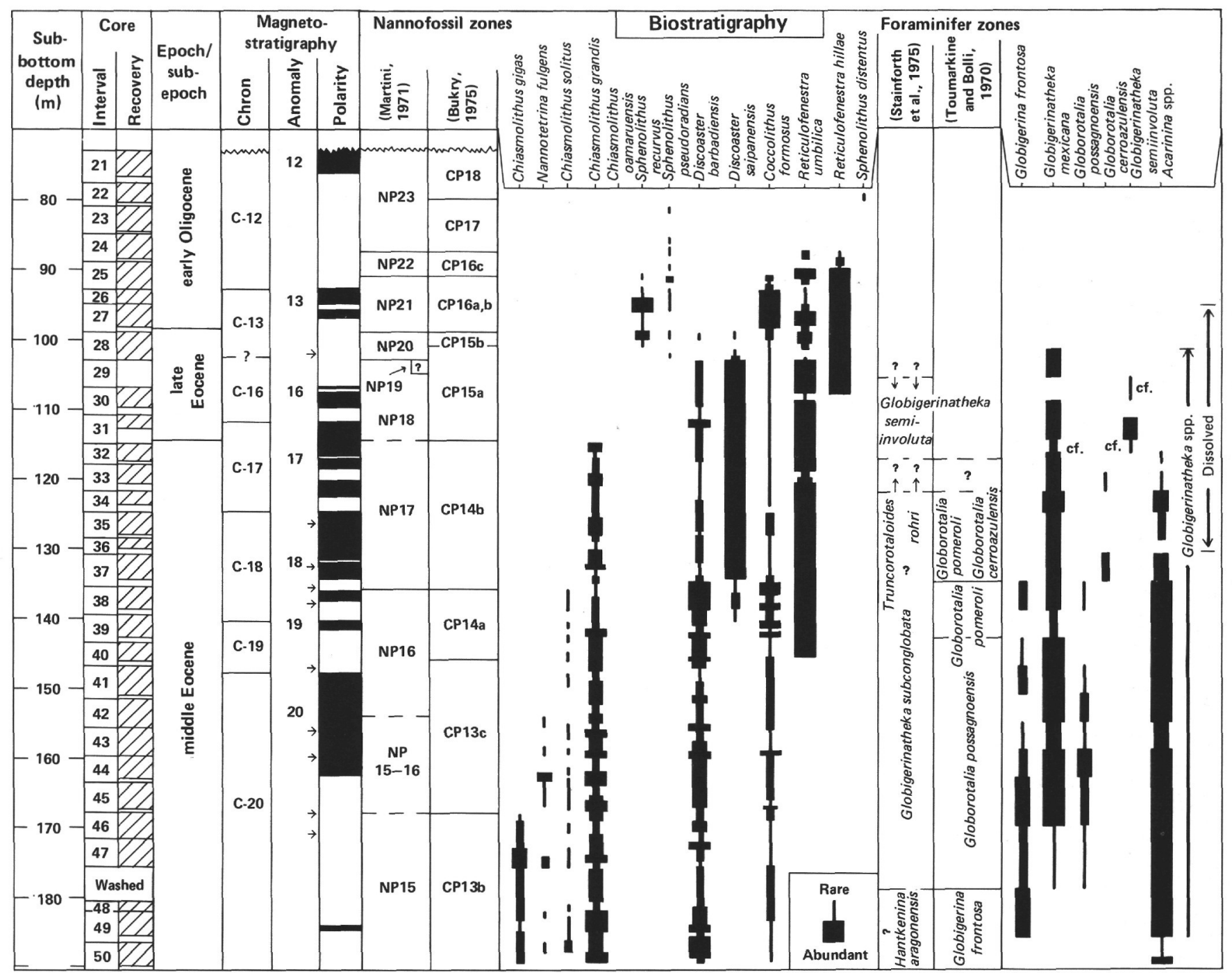

Figure 6. Summary of magnetostratigraphy and biostratigraphy for Hole 523. Arrows next to polarity column show events too brief to plot; cf. = tentative identification. Zone boundaries are plotted between control points.

thus the base of NP19 is within the unrecovered interval of Core 29.

The foraminifer zonation of Stainforth et al. (1975) is difficult to recognize in Hole 523 because of the absence of primary zonal markers and the strong dissolution of the microfossil assemblages above Core 37. In fact, washed residues from Cores 32 through 28 consist almost solely of fragments of the robust genus Globigerinatheka. Some zonal assignments, are possible, however. The occurrence of Globigerinatheka mexicana in Core 47 marks the lower limit of the G. subconglobata Zone. Assemblages in Cores 48 through 50, which contain Pseudohastigerina micra, are assigned to the Hantkenina aragonensis Zone. Robust representatives of Acarinina, which became extinct near the top of the Truncorotaloides rohri Zone, occur consistently up to Core 34. A few specimens are present in Samples 33,CC and $32, \mathrm{CC}$. One could use either the last relatively common occurrence of Acarinina in Core 34 or the few specimens in Sample 32,CC to approximate the upper limit of the $T$. rohri Zone, and both possibilities are shown in
Figure 6. Forms very close to Globigerinatheka semiinvoluta occur in Core 32, and G. semiinvoluta is definitely present in Core 31. These occurrences support the placement of the top of the Truncorotaloides rohri Zone near the base of Core 32 .

The Globorotalia cerroazulensis bioseries is fairly well represented in the lower part of the section, and several of the zones based on changes in that lineage can be recognized. The interpretations shown in Figure 6 assume that the occurrence of $G$. frontosa in Core 38 is due to reworking.

Epoch and subepoch assignments are based on biostratigraphy. Both calcareous nannofossils and planktonic foraminifers indicate that the lower part of the section is middle Eocene and that Core $\mathbf{5 0}$ is near but not at the base of the middle Eocene. Most time-scale models (e.g., Hardenbol and Berggren, 1978) correlate the middle/late Eocene boundary, the NP17/NP18 boundary, and the top of the T. rohri Zone (i.e., "P"'14/"P"'15 boundary). Calcareous nannofossils from Hole 523 indicate that the middle/late Eocene boundary 
is near the top of Core 32, whereas foraminifers indicate that the boundary is slightly lower, perhaps near the base of Core 32. As mentioned above, the foraminifer assemblages from this part of Hole 523 are badly dissolved, so the discrepancy is considered to be minor, and nannofossil data are used to established the middle/late Eocene boundary in Figure 6. The Eocene/Oligocene boundary is identified by the last occurrences of Discoaster barbadiensis and D. saipanensis.

The Hole 523 calibrations provide additional evidence that the Eocene/Oligocene boundary falls within Subchron C-13-R and further show that the middle/late Eocene boundary is near the top of Chron C-17. The latter boundary differs slightly from that proposed by Lowrie et al. (1982), which is based on foraminifer data and is placed near the base of Chron C-17.

\section{SITE 524}

Figure 7 summarizes the magneto- and biostratigraphies for Hole 524. This hole was cored with conventional rotary techniques. Therefore, the Leg 73 HPC core-catcher convention was not applied to Hole 524 . Coring above Core 4 was discontinuous, and the cores recovered were too disturbed for magnetic analysis. Basalts recovered at the base of the sedimentary section in Core 29 represent the top of a sill complex, not basement.

Comparison of the polarity pattern in Cores 12 through 29 to the standard magnetic anomaly pattern and paleontologic data from Hole 524 permits the confident identification of Chrons C-31 through C-27. The normal interval in Core 5 could be Subchron C-26-N or Subchron C-25-N. If calibrations from the Gubbio section in Italy are accepted, the event in Core 5 is Subchron C-26-N (Premoli-Silva, 1977; Roggenthen and Napoleone, 1977). However, preliminary results from DSDP Leg 74 indicate that the NP6/NP7 boundary is near the top of Subchron C-26-N (W. A. Berggren, pers. comm., 1982). Thus, Leg 74 data suggest that Subchron C-26-N occurs in the unrecovered interval of Core 6 and that the normal interval in Core 5 is Subchron C-25-N. The interpretation based on DSDP Leg 74 results is shown in Figure 7.

Calcareous nannofossils are generally abundant and moderately well preserved throughout the section. The lowest occurrences of Nephrolithus frequens and Micula murus are used to establish the lower limits of the latest Cretaceous (late Maestrichtian) $N$. frequens and $M$. murus Zones. The lowest occurrence of Zygodiscus sigmoides in Section 3 of Core 20, which is followed by a rapid decrease in the abundance of typical Cretaceous nannofossils, indicates that the Cretaceous/Tertiary boundary and the base of NP1 are in the lower part of Core 20. The lowest occurrence of Cruciplacolithus tenuis, the primary marker for NP2, coincides with the lowest occurrence of Chiasmolithus danicus, the marker for NP3. Rather than infer an unconformity, we prefer to use the lowest occurrence of Cruciplacolithus edwardsi and Coccolithus pelagicus (s. ampl.) to approximate the base of Zone NP2. The last occurrence of $\mathrm{He}$ liolithus kleinpellii is used to approximate the base of
NP8, because $H$. riedeli is not present in Hole 524 assemblages. The other zone boundaries are based on occurrences of primary markers.

Foraminifer assemblages from Core 28 are referred to the Upper Cretaceous Globotruncana gansseri Subzone because of the occurrence of moderately plicate $G$. contusa; the occurrence of highly plicate $G$. contusa in Core 27, followed by the occurrence of Abathomphalus mayaroensis in Sample 524-26,CC, is indicative of the $A$. mayaroensis Subzone. Interpretation of foraminifer faunas from Cores 20 through 17 is difficult. Assemblages from the lower part of Core 20 contain Cretaceous taxa, minute globigerinids, and forms similar to Globoconusa daubjergensis. Assemblages from Section 1 of Core 20 contain typical $G$. daubjergensis, forms similar to Subbotina pseudobulloides, and various Subbotina spp. The assemblages from the top of Core 20 are too complex to be basal Danian. Thus, the lower part of Core 20 is assigned to the "Globigerina eugubina" Zone, and the upper part is assigned to the $S$. pseudobulloides Zone. Assemblages from Core 19 contain $S$. inconstans, and the assemblage from Core 17 contains specimens simliar to $S$. trinidadensis. These data suggest that the base of the $S$. trinidadensis Zone is in Core 18. An alternative interpretation would be to use the lowest occurrence of $S$. inconstans to approximate the base of the $S$. trinidadensis Zone between Cores 20 and 19. The remaining foraminifer zone boundaries shown in Figure 7 are based on the occurrences of primary indicators, except for the base of the Morozovella angulata Zone, which is inferred to occur in the unsampled interval of Core 12.

Figure 7 shows that the Micula murus Zone extends down through Subchron C-30-N. Because of the sparseness of $M$. murus in the Hole 524 flora, our data probably set an upper limit for the base of the $M$. murus Zone. The $A$. mayaroensis Zone also extends down into Subchron C-31-N. The latter calibration agrees with data from the Gubbio section (Alvarez et al., 1977). Data from Hole 524 further corroborate previous calibrations that show that the Cretaceous/Tertiary boundary as recognized by marine microfossils occurs in the reversed polarity interval between Anomalies 30 and 29, or Subchron C-29-R.

Direct calibrations of magnetostratigraphy and foraminifer biostratigraphy are available for the Paleocene from the Gubbio area (Roggenthen and Napoleone, 1977; Lowrie et al., 1982). Unfortunately, calcareous nannofossils are not preserved in the Paleocene of these sections. Comparison of our calibrations with those made at Gubbio reveals two significant differences. The Gubbio calibrations place the base of the Morozovella uncinata Zone at the top of Subchron C-27-N and the base of the Planorotalites pseudomenardii Zone within C-26-R. Hole 524 calibrations put the base of the M. uncinata Zone in Subchron C-27-R and suggest that the base of the $P$. pseudomenardii Zone is in Subchron C-25-R. M. uncinata is well developed in Hole 524 assemblages; thus, the base of the $M$. uncinata Zone shown in Figure 7 is considered reliable. Identification of the first occurrence of $P$. pseudomenardii in Hole 524 may 


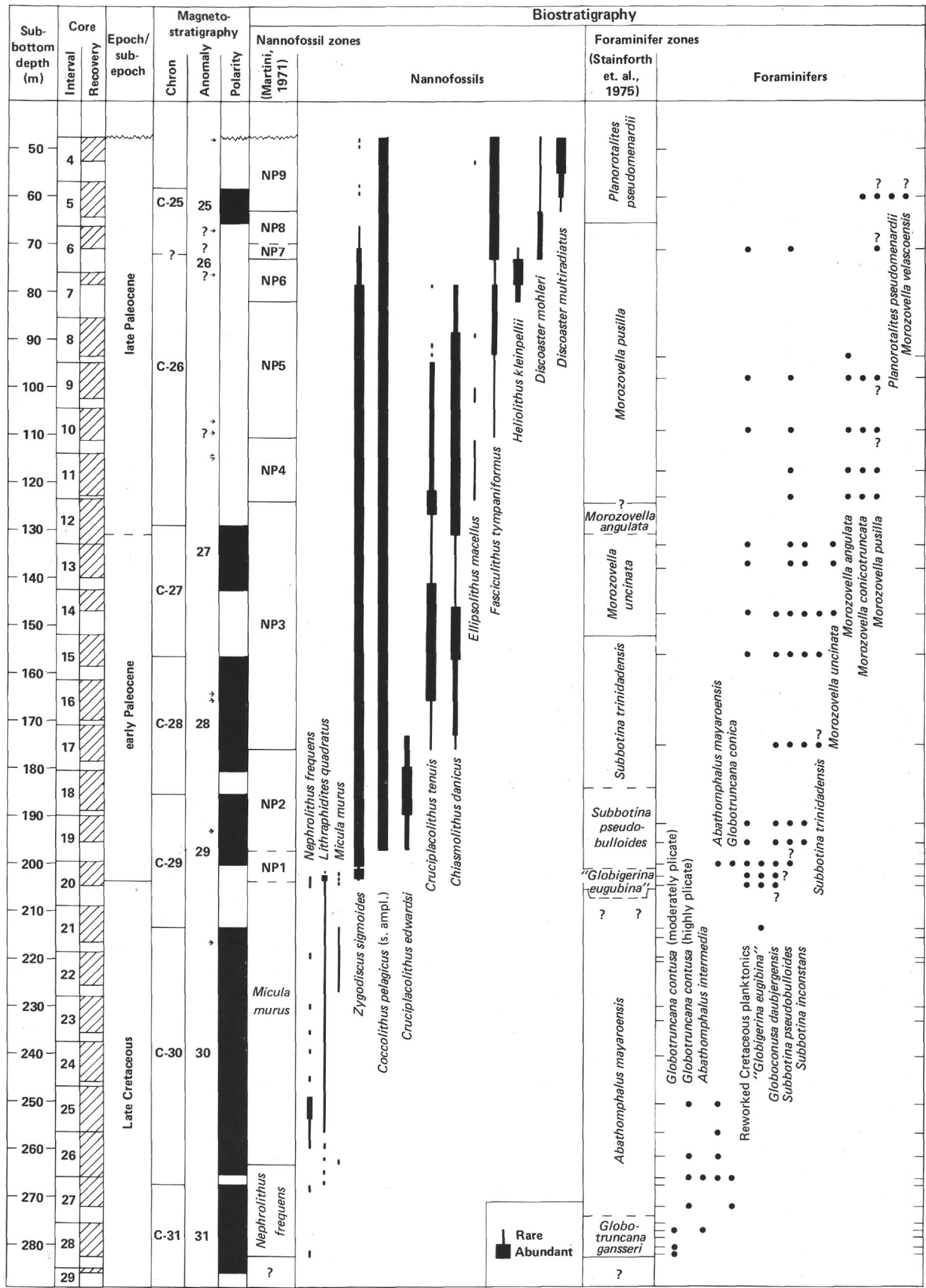

Figure 7. Summary of magnetostratigraphy and biostratigraphy for Hole 524. Arrows next to polarity column show events too brief to plot. Foraminifer occurrences are shown by dots, and samples examined for foraminifers are indicated by short lines at sides of occurrence column. Abundance estimates were not plotted for foraminifers because of highly variable preservation, common reworking, and difficulty in interpreting taxonomic composition of lower Paleocene assemblages. ? = questionable identification. Zone boundaries are plotted between control points. 
be complicated by poor core recovery and wide sampling interval.

\section{ACKNOWLEDGMENTS}

We thank W. A. Berggren and J. E. Hazel for constructive comments on a draft of this manuscript. We also thank Linda Gosnell for technical assistance with the figures.

\section{REFERENCES}

Alvarez, W., Arthur, M. A., Fischer, A. G., Lowrie, W., Napoleoene, G., Premoli Silva, I., and Roggenthen, W. M., 1977. Upper Cretaceous-Paleocene magnetic stratigraphy at Gubbio, Italy. V. Type section for the Late Cretaceous-Paleocene geomagnetic reversal time scale. Geol. Soc. Am. Bull., 88:383-389.

Berggren, W. A., 1973. The Pliocene time scale: calibration of planktonic foraminiferal and calcareous nannoplankton zones. Nature, 243:391-397.

1977. Late Neogene planktonic foraminiferal biostratigraphy of the Rio Grande Rise (South Atlantic). Mar. Micropaleontol., 2:265-313.

Blow, W. H., 1969. Late middle Eocene to Recent planktonic foraminiferal biostratigraphy. In Brönnimann, P., and Renz, H. H. (Eds.), Proc. First Planktonic Conf.: Leiden (E. J. Brill), pp. 199-422.

Bukry, D., 1973. Low-latitude coccolith biostratigraphic zonation. In Edgar, N. T., Saunders, J. B., et al., Init. Repts. DSDP, 15: Washington (U.S. Govt. Printing Office), 685-703.

1975. Coccolith and silicoflagellate stratigraphy, northwestern Pacific Ocean, Deep Sea Drilling Project, Leg 32. In Larson, R. L., Moberly, R., et al., Init. Repts. DSDP, 32: Washington (U.S. Govt. Printing Office), 677-701.

Gartner, S., 1973. Absolute chronology of the late Neogene calcareous nannofossil succession in the equatorial pacific. Geol. Soc. Am. Bull., 84:2021-2033.

Hardenbol, J., and Berggren, W. A., 1978. A new Paleogene numerical time scale. Stud. Geol. Tulsa Okla., 6:213-234.

Haq, B. U., and Berggren, W. A., 1978. Late Neogene calcareous plankton biochronology of the Rio Grande Rise (South Atlantic Ocean). J. Paleontol., 52:1167-1194.

Hays, J. D., Saito, T., Opdyke, N. D., and Burckle, L. H., 1969. Pliocene-Pleistocene sediments of the equatorial Pacific: their paleoclimatic, biostratigraphic and climatic record. Geol. Soc. Am. Bull., 80:1481-1514.

Heirtzler, J. R., Dickson, G. O., Herron, E. N., Pitman, W. C., III, and LePichon, X., 1968. Marine magnetic anomalies, geomagnetic field reversals, and motions off the ocean floor and continents. $J$. Geophys. Res., 73:2119-2136.

Keller, G., Barron, J. A., and Buckle, L. H., in press. North Pacific Late Miocene correlations using microfossils, stable isotopes, percent $\mathrm{CaCO}_{3}$ and magnetostratigraphy. Mar. Micropaleontol.
LaBrecque, J. L., Kent, D. V., and Cande, S. C., 1977. Revised magnetic polarity time scale for Late Cretaceous and Cenozoic time. Geology, 5:330-335.

Lowrie, W., and Alvarez, W., 1981. One hundred million years of geomagnetic polarity history. Geology, 9:392-397.

Lowrie, W., Alvarez, W., Napoleone, G., Perch-Nielsen, K., Premoli Silva, I., and Toumarkine, M., 1982. Paleogene magnetic stratigraphy in Umbrian pelagic carbonate rocks: the Contessa Sections, Gubbio. Geol. Soc. Am. Bull., 93:414-432.

Mankinen, E. A., and Dalrymple, G., B., 1979. Revised geomagnetic polarity time scale for the interval 0-5 m.y.B.P. J. Geophys. Res., 84:615-626.

Martini, E., 1971. Standard Tertiary and Quaternary calcareous nannoplankton zonation. In Farinacci, A. (Ed.), Proc. Second Planktonic Conf.: Rome (E. Tecnoscienza), pp. 739-785.

Ness, G., Levi, S., and Couch, R., 1980. Marine magnetic anomaly timescales for the Cenozoic and Late Cretaceous: a precis, critique, and synthesis. Rev. Geophys. Space Phys., 18:753-770.

Okada, H., and Bukry, D., 1980. Supplementary modification and introduction of code numbers to the low-latitude coccolith biostratigraphic zonation (Bukry, 1973; 1975). Mar. Micropaleontol., 5:321-325.

Premoli Silva, I., 1977. Upper Cretaceous-Paleocene magnetic stratigraphy at Gubbio, Italy. II. Biostratigraphy. Geol. Soc. Am. Bull., 88:371-374.

Roggenthen, W. M., and Napoleone, G., 1977. Upper Cretaceous-Paleocene magnetic stratigraphy at Gubbio, Italy. IV. Upper Cretaceous-Paleocene magnetic stratigraphy. Geol. Soc. Am. Bull., 88:378-382.

Ryan, W. B. F., Cita, M. B., Rawson, M. D., Burckle, L. H., and Saito, T., 1975. A paleomagnetic assignment of Neogene stage boundaries and the development of isochronous datum planes between the Mediterranean, the Pacific and Indian oceans in order to investigate the response of the world ocean to the Mediterranean "salinity crisis." Riv. Ital. Paleontol. Stratigraf., 80:631-688.

Saito, T., Burckle, L. H., and Hays, J. D., 1975. Late Miocene to Pleistocene biostratigraphy of equatorial Pacific sediments. In Saito, T., and Burckle, L. H., Late Neogene Epoch Boundaries: New York (Micropaleontology Press), pp. 226-244.

Stainforth, R. M., Lamb, J. L., Luterbacher, H., Beard, J. H., and Jeffords, R. M., 1975. Cenozoic planktonic foraminiferal zonation and characteristics of index forms. Univ. Kans. Paleontol. Contrib. Pap., No. 62.

Toumarkine, M., and Bolli, H. M., 1970. Évolution de Globorotalia cerroazulensis (Cole) dans L'Éocène moyen et superieur de Possagno (Italie). Rev. Micropaleontol., 13:131-145.

Date of Initial Receipt: June 14, 1982 